\title{
Anti-ganglioside anti-idiotypic vaccination: more than molecular mimicry
}

\author{
Ana M. H. Vázquez ${ }^{1}{ }^{*}$, Nely Rodríguez-Zhurbenko ${ }^{1}$ and Ana M. V. López ${ }^{2}$ \\ ${ }^{1}$ Tumor Immunology Direction, Center of Molecular Immunology, Habana, Cuba \\ 2 Innovation Division, Center of Molecular Immunology, Habana, Cuba
}

\section{Edited by:}

Daniel F. Alonso, Quilmes National University, Argentina

\section{Reviewed by:}

Daniel F. Alonso, Quilmes National University, Argentina

Leonardo Fainboim, Buenos Aires

University, Argentina

\section{*Correspondence:}

Ana M. H. Vázquez, Tumor Immunology Direction, Center of Molecular Immunology, 216 Avenue, 15th Street, Atabey, Playa, 11600 Habana, Cuba. e-mail: anita@cim.sld.cu
Surgery, chemotherapy, and radiation therapy are standard modalities for cancer treatment, but the effectiveness of these treatments has reached a plateau. Thus, other strategies are being explored to combine with the current treatment paradigms in order to reach better clinical results. One of these approaches is the active immunotherapy based on the induction of anti-tumor responses by anti-idiotypic vaccination. This approach arose from Jerne's idiotypic network theory, which postulates that B lymphocytes forms a functional network, with a role in the establishment of the immune repertoires, in the regulation of natural antibody production and even in the establishment of natural tolerance. Due to the large potential diversity of the immunoglobulin variable regions, the idiotypes repertoire can mimic the universe of self and foreign epitopes, even those of non-protein nature, like gangliosides. Gangliosides are sialic acid-containing glycolipids that have been considered attractive targets for cancer immunotherapy, based on the qualitative and quantitative changes they suffer during malignant transformation and due to their importance for tumor biology. Although any idiotype could be able to mimic any antigen, only those related to antigens involved in functions relevant for organism homeostasis, and that in consequence has been fixed by evolution, would be able not only to mimic, but also to activate the idiotypic cascades related with the nominal antigen. The present review updates the results, failures and hopes, obtained with ganglioside mimicking anti-idiotypic antibodies and presents evidences of the existence of a natural response against gangliosides, suggesting that these glycolipids could be idiotypically relevant antigens.

Keywords: idiotypic network, anti-idiotypic antibody, ganglioside, vaccine, natural antibodies

\section{GANGLIOSIDES}

Gangliosides are glycosphingolipids present in the outer leaflet of the plasma membranes, where significantly contribute to the surface properties of cells (Sorice et al., 1997). These glycolipids are involved in various cellular functions, including signal transduction (Bremer et al., 1986; Fujitani et al., 2005), regulation of cell proliferation and differentiation (Hakomori, 1970; Sakiyama etal., 1972; Critchley and Macpherson, 1973; Yogeeswaran and Hakomori, 1975), cell-cell recognition (Feizi, 1985), adhesion (Cheresh et al., 1986), and cell death (De Maria et al., 1997, 1998; Kirschnek et al., 2000; Colell et al., 2001). Gangliosides function as the $\mathrm{Ca}^{2+}$ binding co-factor in synaptic transmission (Svennerholm, 1980), and as the co-factor of membrane adenylate cyclase (Partington and Daly, 1979). Furthermore, they interact with, or are the receptors of different bioactive molecules, such as bacterial toxins (Simpson and Rapport, 1971a,b; Van Heyningen et al., 1971; Holmgren et al., 1973, 1980a; Kato and Naiki, 1976; Ledley et al., 1977), glycoprotein hormones (Lee et al., 1976, 1977; Mullin et al., 1976; Holmgren et al., 1980b), type 1 interferon (Besancon and Ankel, 1974; Vengris et al., 1976; Ankel et al., 1980), fibronectin (Kleinman etal., 1979), lymphokines (Higgins etal., 1978; Miura et al., 1979; Poste et al., 1979), and serotonin (Woolley and Gommi, 1965).

The processes accompanying malignant transformation, like oxidative stress, hypoxia, and angiogenesis, as well as the metastasis formation, induce the expression on cell membranes of potential targets for cancer immunotherapy. It has been widely documented that the expression patterns of membrane gangliosides suffer quantitative and qualitative changes during neoplastic transformations (Brady et al., 1969; Hildebrand et al., 1972; Fishman, 1974; Keranen etal., 1976; Portoukalian etal., 1976). Normal melanocytes express predominantly GM3, while GD3 increases when these cells suffer an oncogenic process (Ravindranath et al., 1991). GD3 plays a role in the regulation of cell growth and the induction of angiogenesis by the tumor cells (Hedberg et al., 2000; Zeng et al., 2000; Fredman et al., 2003). Melanoma GD3 carries a ceramide portion with a long chain fatty acid, in contrast with the GD3 expressed in the normal tissues that carries a shorter chain fatty acid (Nudelman et al., 1982). Fucosyl GM1 is a unique structure that is found in small cell lung cancers (SCLC) with a very limited expression in normal tissues (Krug et al., 2004; Tokuda et al., 2006). GD2 is highly expressed on neuro-ectodermal tumors (Heimburg-Molinaro et al., 2011) and in sarcomas (Kailayangiri et al., 2012). This ganglioside is also a cancer stem cells marker and promotes tumorigenesis (Battula et al., 2012).

A very interesting case is the one of $\mathrm{N}$-glycolylated (NeuGc) gangliosides, since these glycolipids are not naturally expressed in humans due to a genetic deletion in the gene that codes the $\mathrm{CMP}-\mathrm{N}$-acetyl hydroxylase, enzyme that catalyzes the conversion of $N$-acetyl to $N$-glycolyl sialic acid (Irie et al., 1998; Irie and 
Suzuki, 1998; Olson and Varki, 2003). However, both direct and indirect studies have indicated that NeuGc is overexpressed in several human tumors (Devine etal., 1991; Kawai et al., 1991; Marquina et al., 1996; Malykh et al., 2001). The most accepted theory for this phenomenon is the incorporation of NeuGc from dietary sources. Free sialic acids from the medium can be taken up into cells via pinocytosis. The content of the resulting pinocytotic vesicles and endosomes would eventually be delivered to the lysosome, where a sialic acid transporter then delivers the molecules into the cytosol (Bardor et al., 2005). Also endogenous synthesis from glycolyl-CoA is a possibility (Malykh et al., 2001). The explanation for the differential expression of these antigens (Ag) in human normal and tumor tissues is that the rapidly growing tumor tissues might be more efficient at scavenging NeuGc. Furthermore, hypoxia induces the expression of sialin, a sialic acid transporter on tumor cells, and enhances the incorporation of the non-human sialic acid from the external milieu (Yin et al., 2006).

The gangliosides are not only attractive targets due to their over-expression on tumor cells membranes but also because of their importance for tumor biology. The metastatic capacity of the cells is strongly affected by the gangliosides expressed on the cell membranes: disialogangliosides GD2 and GD3 participate in the anchoring of the melanoma and neuroblastoma metastatic cells to the extracellular matrix proteins (Cheresh et al., 1986; Fredman et al., 2003). Comparing the ganglioside pattern expressed by the primary tumor or the metastatic cells of a melanoma patient, gangliosides expression was higher in the last ones, especially GD1. There were also abundant $\mathrm{O}$-acetylation of GM2, GD3, and GD2, which were absent in the primary tumor. GM2 is also strongly expressed in prostate metastasis (Zhang et al., 1998), where is found in the areas of tumor cell-to-tumor cell contact indicating a role in cellular interactions and adhesion (Fredman et al., 2003).

Furthermore, gangliosides actively shed from tumors are inserted into the plasmatic membrane of surrounding cells, affecting the function of lymphocytes (Miller and Esselman, 1975; Lengle et al., 1979; Whisler and Yates, 1980; Ladisch et al., 1983; Gonwa et al., 1984), monocytes (Ladisch et al., 1984), natural killer cells (Diatlovitskaia et al., 1985), and antigen-presenting cells (Caldwell et al., 2003; Bennaceur et al., 2006). Gangliosides have been found to shift the cytokine profile from Th1 toward the Th2 in affected cells (Crespo et al., 2006). Negative modulation of CD4 molecule on T lymphocytes has been described for both the $N$-acetylated (Sorice et al., 1995) and the $N$-glycolylated variants (de Leon et al., 2006) of GM3 ganglioside. Gangliosides have been reported to block the nuclear translocation of NF-кB in human monocytes and dendritic cells (Caldwell et al., 2003). GD3, isolated from the polar lipid fraction of ovarian cancer-associated ascites, was shown to be an inhibitory factor that prevents innate immune activation of natural killer $\mathrm{T}$ cells (Webb et al., 2012). GM2 inhibits immunoglobulin production by B cells (Kimata and Yoshida, 1996). In this way tumor released gangliosides reinforce tumor evasion by blocking the immunological surveillance.

Despite the fact that gangliosides are poorly immunogenic, due to their self and glycolipidic nature, several reports show the presence of naturally occurring antibodies, not only in cancer patients, but also in healthy individuals, suggesting that anti-ganglioside reactivity is fixed in the natural antibodies repertoire.

\section{NATURALLY OCCURRING ANTI-GANGLIOSIDE ANTIBODIES}

Natural antibodies are considered humoral mediators of innate immunity and recognize antigens highly conserved throughout evolution (Cojocaru et al., 2009). It has been proposed that natural auto-antibodies and auto-reactive T cells in healthy individuals may be directed to a specific and limited set of self-molecules; this selective autoimmunity has been termed the immunological homunculus (Cohen, 2007). Due to the limited number of mutations in the genes encoding the variable region of these antibodies, the repertoire of these immunoglobulins is highly conserved within species (Cojocaru et al., 2009). Several authors have described their capacity to bind foreign antigens but also self and altered self-antigens, which may be or not of protein nature (Cohen, 2007). These antibodies recognize epitopes associated with pathogens, such as phosphorylcholine of Gram-positive bacteria, lipopolysaccharide (LPS) of Gram-negative bacteria, and various molecules expressed by parasites (Ochsenbein et al., 1999; Baumgarth et al., 2005). For this reason they are considered as a first, quick anti-infection barrier that helps to guarantee the survival since the very beginning of the organisms' life. Among their targets have also been identified intracellular molecules, such as some nuclear (e.g., histones) and cytoskeleton (e.g., actin) proteins (Coutinho et al., 1995) and single-stranded DNA (Schwartz-Albiez et al., 2009). They also recognize peptides (e.g., amyloid beta peptide), plasma membrane glycoproteins (e.g., CD90; SchwartzAlbiez et al., 2009), oxidized lipids (e.g., phosphatidylcholine), and antigens expressed by apoptotic cells (Annexin IV; Chou et al., 2009; Baumgarth, 2011). Mounting evidence suggest that natural IgM antibodies, through this self-reactivity might contribute to critical innate immune functions involved in the maintenance of tissue homeostasis, like the clearance of apoptotic cells (Chou et al., 2009), reduction of atherosclerotic lesions (Hartvigsen et al., 2009; Cesena et al., 2012), and the reinforcement of mechanisms involved in the protection from the development of autoimmune disease (Werwitzke et al., 2005; Chen et al., 2009a,b; Silverman et al., 2009; Jiang et al., 2011; Stoehr et al., 2011).

Recently it has been described the existence of auto-antibodies against tumor-associated antigens, which can arise in the patients even before the symptoms become evident and that can be detected also in healthy donors (Zhang etal., 2003; Storr et al., 2006; Chapman et al., 2008). Some of these IgM isotype, germline antibodies have been isolated from cancer patients and have proved to be able not only to recognize tumor cells, but also to kill them by different mechanisms (Bohn, 1999; Hensel et al., 2001; Jakobisiak et al., 2003; Vollmers and Brandlein, 2005, 2006; Lutz et al., 2009). Many of the detected anti-tumor antibodies bind to carbohydrate repeated motifs, including sequences of sugars contained in gangliosides (Lutz and Miescher, 2008; Cojocaru et al., 2009).

Naturally occurring antibodies reacting with tumor-associated gangliosides have been detected in cancer patients but also in healthy donors. Antibodies against GM2 and GD2 were detected 
in the sera of both melanoma patients and healthy individuals (Watanabe et al., 1982; Tai et al., 1985). Other authors have reported the existence in healthy donors of naturally occurring antibodies with reactivity against gangliosides like GM1, GD1a, GD1b, and GT1b (Mizutamari et al., 1994; Ravindranath et al., 1997; Lardone et al., 2006). Silent auto-reactive B clones have also been identified in cancer patients, from which human monoclonal antibodies ( $\mathrm{mAb}$ ) against gangliosides were generated. The mAb GMA1 reacted with the gangliosides GD3, GM3, and GD2 from melanoma and neuroblastoma cell lines and not normal tissues (Mukerjee et al., 1998). The human monoclonal IgM antibody $7 \mathrm{c} 11 . e 8$, also generated by fusing lymph node cells isolated from a surgical specimen of malignant melanoma reacted with GM4, GM3, and GD3. In the presence of human serum the antibody initiated a strong lysis of melanoma tumor cells in complement-dependent cellular cytotoxicity (CDCC) assays (Abdel-Wahab et al., 1993).

The presence of naturally occurring antibodies that recognize NeuGc acid present in tumor-associated glycoconjugates has also been described. It has been shown that normal human serum contains high levels of NeuGc-specific antibodies, which attract complement molecules to the surface of leukemic cells expressing NeuGc, but not other normal cells (Zhu and Hurst, 2002; Tangvoranuntakul et al., 2003; Nguyen et al., 2005; Padler-Karavani et al., 2008). Ravindranath et al. (2007), examining the sera of healthy volunteers between the ages of 18 and 90, reported that antiganglioside antibodies occurred naturally and that their levels decline after 50 years, which could be relevant since the cancer incidence increases with age.

Anti-ganglioside antibodies have shown to have anti-tumor cytotoxic capacities. It has been reported the ability of a murine anti-GM2 to induce apoptosis through caspase activation in lymphoma, melanoma, and lung cancer cells expressing the antigen (Retter et al., 2005). The binding of an anti-GD2 antibody to the ganglioside expressed in lung cancer cells induced apoptosis by the reduction in the levels of phosphorylation of FAK and activation of mitogen-activated kinase p38. Immunoprecipitation experiments showed a physical association of GD2 with integrins, which were associated with FAK inside the membrane. Antibody binding to ganglioside caused conformational changes in this complex, inducing the transmission of intracellular signals that mediated the apoptosis (Aixinjueluo et al., 2005). It has been also proved that anti-GD2 antibodies of healthy donors have cytotoxic capacity against neuroblastoma cells (Ollert et al., 1997).

The capacity of the mAb 14F7, a murine IgG highly specific for NeuGcGM3, to induce oncotic cell death to tumor cells expressing this antigen has been reported. This antibody induced a tumor cell death that was accompanied by cellular swelling, membrane lesion formation, and cytoskeleton activation (Carr et al., 2000; RoqueNavarro et al., 2008). Another antibody specific for $N$-glycolylated gangliosides is $\mathrm{P} 3 \mathrm{mAb}$. This is an IgM, germline encoded that is able to induce complement-mediated cytotoxicity to NeuGc expressing tumor cells (Vázquez et al., 1995; Carr et al., 2002). It has been reported that naturally occurring anti-NeuGc in healthy humans were able to kill human leukemic cells that were exogenously fed with NeuGc by a complement-mediated mechanism (Nguyen et al., 2005).
These evidences suggest that the evolution has fixed an innate immunity against gangliosides in the natural antibodies repertoire, which could play an important role for tumor immune surveillance. Since the natural antibodies secreting B cells arise in the neonatal period, they could be connected and regulated by anti-Id interactions, according to Jerne's idiotypic network theory.

\section{THE IDIOTYPIC NETWORK THEORY}

In 1974, Neils Jerne published the Idiotypic Network theory, which gave a different view of the immune system organization and the recognition of the "self." According to classical clonal selection theory, the immune system was "antigen driven" and in the absence of an external antigen challenge the system should be passively inactive. In contrast, according to the network theory, the immune system consists of lymphocyte clones which are stimulated and regulated by the immunoglobulins produced by other clones within the network. Since a huge diversity of idiotypes (Id) is generated by random somatic rearrangements of genes, idiotype's complementary structures can be found not only on antigens but also on antibodies of different idiotypes. In Jerne's own words "the immune system of a single animal, after producing specific antibodies to an antigen, continues to produce antibodies to the idiotopes of the antibodies which it has itself made. The latter anti-Id antibodies likewise display new idiotypic profiles, and the immune system turns out to represent a network of idiotypic interactions" (Jerne, 1974, 1985).

This phenomena was extensively proved firstly by Kunkel and Oudin, who showed that ordinary antibody molecules that arise in an immunized animal are antigenic and induce the formation of specific anti-antibodies (Kunkel et al., 1963; Oudin and Michel, 1963). Later experiments further demonstrated that the recognition of self-idiotopes by $\mathrm{B}$ or $\mathrm{T}$ cells is an active physiological process controlling the suppression or expansion of the immune response (Eichmann and Rajewsky, 1975; Cazenave, 1977; Urbain et al., 1977; Bona et al., 1981).

This immune network is established in the neonatal period, thus this theory predicts that the immune systems has an autonomous activity, manifested by the presence of activated lymphocytes and antibody secretion, before any external immunization. This prediction was confirmed by studies on "antigen-free" animals, which contain in their spleen and peritoneal cavity activated $\mathrm{B}$ cells that secret IgM antibodies and T lymphocytes that perform as effector cells, help or suppress the antibody production (Hooijkaas et al., 1984; Pereira et al., 1986).

Thus, a network of idiotypically interacting immune cells is formed, that has a dynamic equilibrium between the idiotypes, anti-Id, and the normal self-constituents of our body, influencing the shaping of the $\mathrm{B}$ - and $\mathrm{T}$ cell repertoires, and controlling autoreactive clones.

In the 1980s, there was an interesting debate between the proponents of the network paradigm and those of the clonal selection theory and several experiments were performed that provided evidences about both ideas (Cohn, 1981, 1986; Langman and Cohn, 1986; Cazenave, 1988; Behn, 2007).

The establishment of collections of antibody-producing hybridomas, derived from normal, unimmunized mice at different stages of ontogeny, provided proof for the existence of idiotypic 
connectivity (Holmberg et al., 1984a). Matrices of idiotypic complementarities were established, that allowed to estimate the degree of connectivity within different B cell populations (Holmberg et al., 1984a,b, 1986a,b,c; Kearney and Vakil, 1986). High levels of connectivity were observed within collections of fetal or neonatal origin (Holmberg et al., 1984b). However, within collections from the adult lymphocyte population the degree of connectivity was 10- to 100-fold lower (Holmberg et al., 1986c). These experiments suggested that high idiotypic connectivity is not an intrinsic property of any collection of IgM antibodies, but a distinctive property of part of the perinatal antibody repertoire.

Then, Varela and Coutinho formulated the concept of secondgeneration immune networks (Coutinho, 1989; Varela and Coutinho, 1991), which tried to combine the two competing paradigms. They adopted the view that the immune system is formed by two compartments of B and T lymphocytes: a majority of small resting cells constituting $80-85 \%$ of the total population and a set of large activated cells making up the other 15-20\% (Pereira et al., 1985, 1986), this last being the predominant in the neonatal period. The specific response to a foreign antigen would be mainly caused by the activation of resting lymphocyte clones, which are only poorly connected to the network, thus forming the peripheral part of the system. The fraction of highly connected cells forms the actual network, a compartment of naturally activated lymphocytes. The immune network includes, in addition to V-regions, all other molecules of the somatic self. This pool of connected cells may be responsible for maintenance of normal network dynamics and prevention of auto-aggression.

The idiotypic network hypothesis predicts that due to the huge diversity of immunoglobulin variable regions, and since each antibody will bind its nominal antigen and also other immunoglobulins, within the immune network the universe of external antigens is mimicked by idiotypes. According to this concept, immunization with a given antigen will generate the production of antibodies against this antigen termed Ab1. This Ab1 can generate a series of anti-Id antibodies against Ab1 termed Ab2. The particular anti-Ids which fit into the antigen binding site of the Ab1, can induce a specific immune responses against the nominal antigen. Then, a practical consequence of the idiotypic network theory was that the idiotopes could be used to mimic any existing antigen and used as surrogate antigens. Immunization with Ab2 can lead to the generation of anti-anti-Id antibodies (Ab3) that recognize the corresponding original antigen identified by the Ab1 (Figure 1). Several such Ab2 have been used to trigger the immune system to induce specific and protective immunity against tumor antigens (Miller et al., 1982; Jerne, 1985; Lee et al., 1985; Raychaudhuri et al., 1986).

Although Jerne, in his original network hypothesis, and later Coutinho with the second generation networks outlined the importance of naturally occurring idiotypic complementaries, must of the studies using anti-Id as vaccines are focus on the great mimetic capacity of idiotypes, no in activating network related properties, like immune regulation and natural immune surveillance. Beyond the functional mimetic capacity, those anti-Id antibodies related with antigens connected and regulated though networks due to their importance for organisms' homeostasis, could be able to activate natural antibodies secreting B cells. Their antigens, especially self-antigens, could be the suited ones to get targeted through the idiotypic vaccination. This could be the case of gangliosides.

\section{ANTI-GANGLIOSIDE IDIOTYPIC VACCINES}

Anti-idiotype antibodies that mimic ganglioside have been utilized as active specific immunotherapy in patients with different tumors. Chapman and Houghton (1991) generated in syngeneic mice the anti-Id antibody BEC2 against the anti-GD3 mAb R24. In studies in rabbits this antibody demonstrated its ability to mimic GD3, inducing a specific antibody response of IgG and IgM isotypes. In clinical trials in melanoma patients treated by surgery and with high risk of recurrence (McCaffery et al., 1996) and in patients with SCLC with limited disease (Grant et al., 1999) BEC2 demonstrated to be immunogenic and to induce anti-anti-Id response when administered with the adjuvant BCG. However, it induced specific anti-GD3 antibodies only in a low percentage of patients (Chapman and Houghton, 1991; McCaffery etal., 1996; Grant et al., 1999). The conjugation of BEC 2 to KLH did not increase but reduced the magnitude and frequency of the anti-GD3 response. When anti-GD3 antibodies were induced, they were detected only by ELISA, not by TLC immunostaining (Ritter et al., 1991) or by flow cytometry against GD3-positive melanoma cell lines, suggesting that these anti-GD3 antibodies had a relatively low avidity for cell surface GD3. A phase III trial with 515 patients with limited-disease SCLC after a major response to chemotherapy and chest radiation was performed with BEC2/BCG. This trial failed to show any survival advantage for vaccinated patients. Only one-third of the patients elicited an anti-GD3 response. Among vaccinated patients, a trend toward prolonged survival was observed in those who developed the humoral response $(P=0.085)$, so that it was suggested that the induction of higher titers of antibodies in a larger proportion of patients could make an impact on median survival (Giaccone et al., 2005).

Another trial that targeted a ganglioside, utilized a vaccine composed of an anti-Id mimicking GD2 injected with the adjuvant QS21, a preparation called TriGem. The anti-Id mAb, called 1A7 is a functional mimic of a specific epitope in the ganglioside GD2. In preclinical studies in mice, rabbits, and monkeys the immunization with $1 \mathrm{~A} 7$ antibody induced a specific IgG response against the ganglioside, capable of causing the lysis of GD2-positive cells on ADCC assays (Sen et al., 1998).

Foon etal. (1998) initiated a clinical trial in patients with advanced melanoma, which were given anti-Id mAb $1 \mathrm{~A} 7$ with the adjuvant QS21. All sera showed an anti-anti-Id response mainly of the IgG1 isotype. The purified Ab3 from all patients inhibited the binding of the Ab1 to a GD2-positive cell line and to purified GD2. In addition, sera specifically reacted with tumor cells expressing GD2 and were positive in ADCC studies. One patient had a complete clinical response and 6 patients, of a total of 12 enrolled in the trial were stable from 9 to 23 months. In a similar trial, 47 patients with advanced melanoma received 1 , 2, 4, or $8 \mathrm{mg}$ doses of TriGem. Hyperimmune sera from 40 of the 47 patients showed an anti-anti-Id response of IgG isotype that specifically bound purified GD2. One patient had a complete response that persisted at 24 months, and 12 patients were stable 


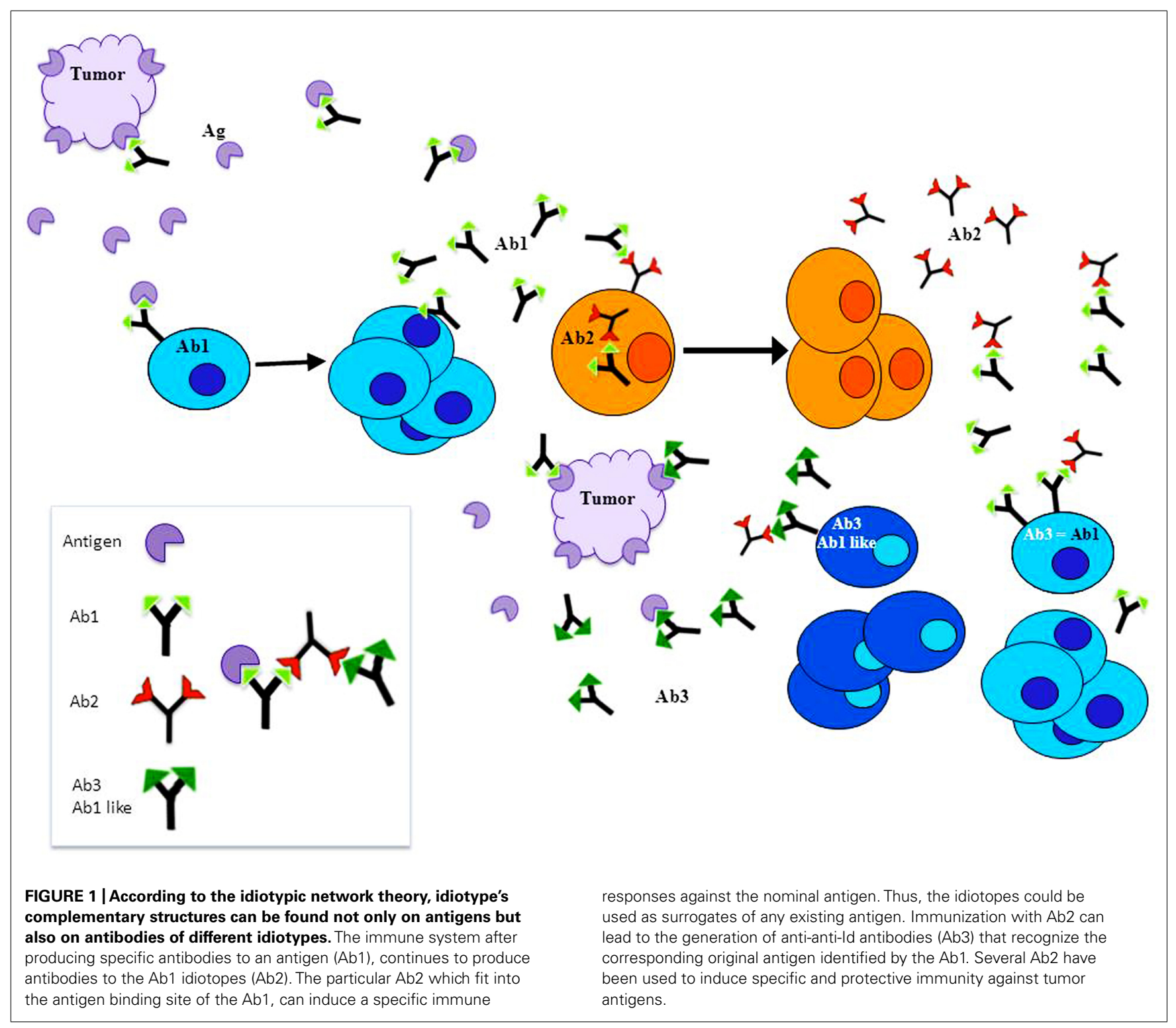

from 14 to 37 months (median, 18 months). These results showed that this vaccine had minimal toxicity, induced a strong response against GD2 and seemed to have a favorable impact on the reduction of disease progression and survival of patients (Foon et al., 1998, 2000).

In 2003, Basak and colleagues generated Ab2 against the antiGD2 mAb ME361. These Ab2s induced a specific DTH response in mice against melanoma cell lines that express this ganglioside. Furthermore, these antibodies were able to induce proliferative responses in cells from a melanoma patient confronted with human melanoma cells expressing GD2 in vitro, demonstrating the ability of these antibodies to induce cellular responses against carbohydrate antigens (Basak et al., 2003).

Several evidences have shown that tumor antigen-specific antibodies Ab1, used in preclinical experiments or for diagnostic and/or therapeutic purposes, may contribute to anti-tumor effects by triggering the idiotypic cascade and inducing a tumor antigen-specific immune response. The triggering of the idiotypic cascade has been reported to be associated with a favorable clinical response to antibody-based therapy in patients with neuroblastoma, colorectal carcinoma, ovarian carcinoma, and non-Hodgkin lymphoma (Koprowski et al., 1984; Saleh et al., 1993; Cheung et al., 1994, 2000; Schultes et al., 1998). GD2 ganglioside-specific antibodies have been induced in patients with neuroblastoma treated with anti-GD2 ganglioside antibodies.

Treatment with the anti-GD2 monoclonal antibody 3F8 (Ab1) at the time of remission prolonged the survival of children with stage 4 neuroblastoma. Among 34 patients treated with this antibody at the end of chemotherapy 14 were alive, and 13 (1.8-7.4 years at diagnosis) were progression-free (53-143 months from the initiation of $3 \mathrm{~F} 8$ treatment) without further systemic therapy at the moment of the report. This long-term progression-free survival and survival correlated significantly with the induction of Ab3 anti-GD2 response (Cheung et al., 2000). These results reinforce 
the importance of GD2 as a tumor target, and the connectivity capacity of anti-ganglioside antibodies.

Our group has developed a vaccine preparation featuring a murine anti-Id $\mathrm{mAb}$ related to the NeuGc-containing ganglioside antigen model. This Ab2, named 1E10 (Vázquez et al., 1998), was generated from the immunization of BALB/c mice with P3, an idiotypic antibody (Ab1) that recognizes NeuGc-containing gangliosides, sulfated glycolipids, and antigens present in different human tumors including those from the lung. This $\mathrm{Abl}$ is highly immunogenic in the syngeneic model, inducing an anti-Id response in the absence of adjuvant or carrier protein. Furthermore, the Ab1 P3 was able to activate NeuGcGM3 related idiotypic cascade, since antibodies against NeuGcGM3 (Ab3, Ab1 like) were detected in chickens immunized with this Abl. The detection of Abs with this specificity in animals immunized with an Ab1 suggested that the elicited Ab2s behaved as a ganglioside surrogate inducing a specific $\mathrm{Ab} 3$ response against this antigen.

Preclinical data published by our group suggest that P3 and $1 \mathrm{E} 10 \mathrm{mAb}$ could be able to activate idiotypic networks, involving both B and T cells. Lymph node cells from BALB/c mice immunized with $\mathrm{P} 3 \mathrm{mAb}$ proliferated in vitro, in a dose-dependent manner, not only in response to $\mathrm{P} 3 \mathrm{mAb}$ but also to $1 \mathrm{E} 10$ $\mathrm{mAb}$, suggesting the existence of a naturally occurring $\mathrm{B} / \mathrm{T}$ cell idiotypic network (Perez et al., 2002). Phase I clinical trials have proven the safety and immunogenicity of 1 E10 Id vaccination in melanoma, breast, and lung cancer patients (Alfonso et al., 2002, 2007; Diaz etal., 2003; Neninger et al., 2007; Hernandez etal., 2008). In all the cases, 1E10 idiotype proved to be immunodominant, since the induced anti-anti-Id response was significantly higher than the anti-isotypic response. Similar results were obtained when monkeys and chickens were immunized with $1 \mathrm{E} 10 \mathrm{mAb}$ (Hernandez et al., 2005), suggesting that $1 \mathrm{E} 10 \mathrm{mAb}$ Id immunodominance is not a species-depending property. High titer antibody responses to NeuGc-containing gangliosides were measured in the sera of cancer patients and were confirmed by TLC immunostaining. Interestingly, a fraction of non-suppressible anti-NeuGc-containing ganglioside Abs was demonstrated after the adsorption of the patients' sera with 1E10 $\mathrm{mAb}$, suggesting that $1 \mathrm{E} 10 \mathrm{Id}$ vaccination was activating natural anti-NeuGcGM3 responses (Hernandez et al., 2008). The antibodies that recognize both $1 \mathrm{E} 10$ and the ganglioside $\left(\mathrm{Id}^{+} \mathrm{Ag}^{+}\right)$and the ones that recognize the ganglioside but not the immunizing Ab3 $\left(\mathrm{Id}^{-} \mathrm{Ag}^{+}\right)$, recognized and induced the death of tumor cells expressing NeuGcGM3 by an oncotic necrosis mechanism. Those patients who developed IgG and/or IgM Abs against NeuGcGM3 showed a longer survival time. We hypothesize that 1E10 Id vaccination could be activating an existing idiotypic cascade related with $N$-glycolylated gangliosides, which would amplify
Summary of highlight milestones in the development of anti-idiotypic vaccination against tumor gangliosides.
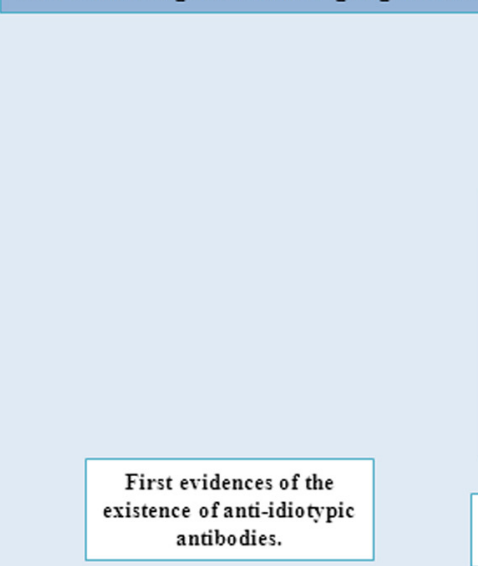

First evidences of the regulatory properties of the idiotypic networks and B-T idiotypic interactions. Establishment of collections of antiidiotypic hybridomas provided proof of natural idiotypic connectivity and its characteristics in newboms and adults. First evidences of anti-tumor antiidiotypic vaccination.

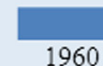

1960
1970

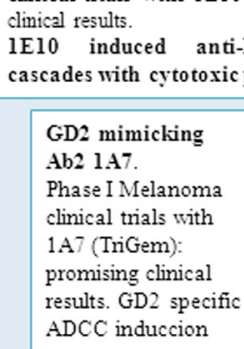
clinical results.

GD2 mimicking

Ab2 1. 7 .

Phase I Melanoma

clinical trials with

1A7 (TriGem):

promising clinical

results. GD2 specific

$\mathrm{ADCC}$ induccion

NeuGcGM3 mimicking Ab2 1E10

Phase I melanoma, breast, SCLC and NSCLC clinical trials with $1 \mathrm{E} 10$ (Racotumomab): promising

$1 E 10$ induced anti-NeuGCGM3 idiotypic cascades with cytotoxic properties

GD3 mimicking Ab2 Bec2.

Phase III SCLC clinical trial with Bec2: No survival advantage for the vaccine.. Trend toward longer survival for anti-GD3 responders

qualitative and quantitative changes in ganglioside expression during neoplastic transformation

Gangliosides are important for tumor biology : influence the metastatic, angiogenic and anti-immune capacities.

Detection of naturally occurring antibodies against gangliosides in cancer patients and healthy individuals.

Anti-ganglioside antibodies display ganglioside specific antitumor cytotoxicity. 
the antigen-specific immune response to a tumor-associated neoself antigens. This therapeutic concept goes beyond the classical concept of antigen mimicry. A randomized, double blind phase II clinical trial is ongoing to evaluate the clinical effect of $1 \mathrm{E} 10$ $m A b$ vaccine in NSCLC patients and to define the value of the Abs induced by the anti-Id treatment as real predictors of clinical outcome. For a chronological representation of the principal milestones in the development of anti-Id vaccines against tumor expressed gangliosides see Figure 2 .

\section{CONCLUDING REMARKS}

At present, most of the anti-Id vaccine approaches are based and study the mimetic capacity of the anti-Id antibodies, without searching for their immunoregulatory or natural anti-tumor

\section{REFERENCES}

Abdel-Wahab, Z., Li, W. P., Darrow, T., Nudelman, E. D., Towell, A., and Seigler, H. F. (1993). Cell surface reactive human monoclonal antibody directed to human melanomaassociated gangliosides. Melanoma Res. 3, 415-423.

Aixinjueluo, W., Furukawa, K., Zhang, Q., Hamamura, K., Tokuda, N., Yoshida, S., et al. (2005). Mechanisms for the apoptosis of small cell lung cancer cells induced by antiGD2 monoclonal antibodies: roles of anoikis. J. Biol. Chem. 280, 2982829836.

Alfonso, M., Diaz, A., Hernandez, A. M., Perez, A., Rodriguez, E., Bitton, R., et al. (2002). An anti-idiotype vaccine elicits a specific response to $N$-glycolyl sialic acid residues of glycoconjugates in melanoma patients. J. Immunol. 168, 2523-2529.

Alfonso, S., Diaz, R. M., De La Torre, A., Santiesteban, E., Aguirre, F., Perez, K., et al. (2007). 1E10 anti-idiotype vaccine in non-small cell lung cancer: experience in stage IIIb/IV patients. Cancer Biol. Ther. 6, 18471852.

Ankel, H., Krishnamurti, C., Besancon, F., Stefanos, S., and Falcoff, E. (1980). Mouse fibroblast (type I) and immune (type II) interferons: pronounced differences in affinity for gangliosides and in antiviral and antigrowth effects on mouse leukemia L-1210R cells. Proc. Natl. Acad. Sci. U.S.A. 77, 2528-2532.

Bardor, M., Nguyen, D. H., Diaz, S., and Varki, A. (2005). Mechanism of uptake and incorporation of the non-human sialic acid $N$ glycolylneuraminic acid into human cells. J. Biol. Chem. 280, 4228-4237.

Basak, S., Birebent, B., Purev, E., Somasundaram, R., Maruyama, H., Zaloudik, J., et al. (2003). Induction of cellular immunity by anti-idiotypic antibodies mimicking
GD2 ganglioside. Cancer Immunol. Immunother. 52, 145-154.

Battula, V. L., Shi, Y., Evans, K. W., Wang, R. Y., Spaeth, E. L., Jacamo, R. O., et al. (2012). Ganglioside GD2 identifies breast cancer stem cells and promotes tumorigenesis. J. Clin. Invest. 122, 2066-2078.

Baumgarth, N. (2011). The double life of a B-1 cell: self-reactivity selects for protective effector functions. Nat. Rev. Immunol. 11, 34-46.

Baumgarth, N., Tung, J. W., and Herzenberg, L. A. (2005). Inherent specificities in natural antibodies: a key to immune defense against pathogen invasion. Springer Semin. Immunopathol. 26, 347-362.

Behn, U. (2007). Idiotypic networks: toward a renaissance? Immunol. Rev. 216, 142-152.

Bennaceur, K., Popa, I., Portoukalian, J., Berthier-Vergnes, O., and PeguetNavarro, J. (2006). Melanomaderived gangliosides impair migratory and antigen-presenting function of human epidermal Langerhans cells and induce their apoptosis. Int Immunol. 18, 879-886.

Besancon, F., and Ankel, H. (1974). Binding of interferon to gangliosides. Nature 252, 478-480.

Bohn, J. (1999). Are natural antibodies involved in tumour defence? Immunol. Lett. 69, 317-320.

Bona, C. A., Heber-Katz, E., and Paul, W. E. (1981). Idiotype-anti-idiotype regulation. I. Immunization with a levan-binding myeloma protein leads to the appearance of auto-anti-(antiidiotype) antibodies and to the acti153, 951-967.

Brady, R. O., Borek, C., and Bradley, R. M. (1969). Composition and synthesis of gangliosides in rat hepatocyte and hepatoma cell lines. J. Biol. Chem. 244, 6552-6554.

Bremer, E. G., Schlessinger, J., and Hakomori, S. (1986). vation of silent clones. J. Exp. Med.

potential. The use of anti-Id antibodies as immunogens could offer the possibility not only to generate $\mathrm{Ab} 3$ antibodies against their own idiotopes, but also to inducing a cascade of Id-antiId interactions leading to an amplified and long lasting immune response against the nominal antigen. This immunization could also involve $\mathrm{T}$ cells in the response against glycolipidic antigens. The expansion of natural antibodies repertoire by idiotypic vaccination could even participate in the lysis of tumor cells by the activation of evolutionarily fixed anti-tumor mechanisms. A naturally occurring antibody response against ganglioside, which has shown to carry anti-tumor properties, exists in healthy individuals and cancer patients. The idiotypic vaccination could be an optimum way to activate the idiotypic $\mathrm{B}$ and $\mathrm{T}$ cell cascades involving the natural responses against these antigens.

Ganglioside-mediated modulation of cell growth. Specific effects of GM3 on tyrosine phosphorylation of the epidermal growth factor receptor. J. Biol. Chem. 261, 24342440.

Caldwell, S., Heitger, A., Shen, W., Liu, Y., Taylor, B., and Ladisch, S. (2003). Mechanisms of ganglioside inhibition of APC function. J. Immunol. 171, 1676-1683.

Carr, A., Mesa, C., Del Carmen Arango, M., Vázquez, A. M., and Fernandez, L. E. (2002). In vivo and in vitro anti-tumor effect of $14 \mathrm{~F} 7$ monoclonal antibody. Hybrid. Hybridomics $21,463-468$.

Carr, A., Mullet, A., Mazorra, Z., Vázquez, A. M., Alfonso, M., Mesa, C., etal. (2000). A mouse IgG1 monoclonal antibody specific for $\mathrm{N}$-glycolyl GM3 ganglioside recognized breast and melanoma tumors. Hybridoma 19, 241-247.

Cazenave, P. A. (1977). Idiotypic-antiidiotypic regulation of antibody synthesis in rabbits. Proc. Natl. Acad. Sci. U.S.A. 74, 5122-5125.

Cazenave, P. A. (1988). Idiotypy. Ann. Inst. Pasteur Immunol. 139C, 597708.

Cesena, F. H., Dimayuga, P. C., Yano, J., Zhao, X., Kirzner, J., Zhou, J., etal. (2012). Immunemodulation by polyclonal $\operatorname{IgM}$ treatment reduces atherosclerosis in hypercholesterolemic $\mathrm{apoE}^{-/-}$ mice. Atherosclerosis 220, 59-65.

Cohen, I. R. (2007). Biomarkers, self-antigens and the immunological homunculus. J. Autoimmun. 29, 246-249.

Cohn, M. (1981). Conversations with Niels Kaj Jerne on immune regulation: associative versus network recognition. Cell. Immunol. 61, 425-436.

Cohn, M. (1986). Comments on the Forum "Is the immune system a functional idiotypic network?"
Ann. Inst. Pasteur Immunol. 137C, 173-188.

Cojocaru, M., Cojocaru, I. M., and Silosi, I. (2009). The significance of natural autoantibodies. Moedica 4, 22-25.

Colell, A., Garcia-Ruiz, C., Roman, J., Ballesta, A., and Fernandez-Checa, J. C. (2001). Ganglioside GD3 enhances apoptosis by suppressing the nuclear factor-kappa B-dependent survival pathway. FASEB J. 15, 10681070.

Coutinho, A. (1989). Beyond clonal selection and network. Immunol. Rev. 110, 63-87.

Coutinho, A., Kazatchkine, M. D., and Avrameas, S. (1995). Natural autoantibodies. Curr. Opin. Immunol. 7 , 812-818.

Crespo, F. A., Sun, X., Cripps, J. G., and Fernandez-Botran, R. (2006). The immunoregulatory effects of gangliosides involve immune deviation favoring type-2 $\mathrm{T}$ cell responses. $J$. Leukoc. Biol. 79, 586-595.

Critchley, D. R., and Macpherson, I. (1973). Cell density dependent glycolipids in NILz hamster cells, derived malignant and transformed cell lines. Biochim. Biophys. Acta 296, 145-159.

Chapman, C. J., Murray, A., Mcelveen, J. E., Sahin, U., Luxemburger, U., Tureci, O., et al. (2008). Autoantibodies in lung cancer: possibilities for early detection and subsequent cure. Thorax 63, 228-233.

Chapman, P. B., and Houghton, A. N. (1991). Induction of IgG antibodies against GD3 ganglioside in rabbits by an anti-idiotypic monoclonal antibody. J. Clin. Invest. 88, 186-192.

Chen, Y., Khanna, S., Goodyear, C. S., Park, Y. B., Raz, E., Thiel, S., etal. (2009a). Regulation of dendritic cells and macrophages by an anti-apoptotic cell natural antibody that suppresses TLR responses and 
inhibits inflammatory arthritis. $J$. Immunol. 183, 1346-1359.

Chen, Y., Park, Y. B., Patel, E., and Silverman, G. J. (2009b). IgM antibodies to apoptosis-associated determinants recruit $\mathrm{Clq}$ and enhance dendritic cell phagocytosis of apoptotic cells. $J$. Immunol. 182, 6031-6043.

Cheresh, D. A., Pierschbacher, M. D., Herzig, M. A., and Mujoo, K. (1986). Disialogangliosides GD2 and GD3 are involved in the attachment of human melanoma and neuroblastoma cells to extracellular matrix proteins. J. Cell Biol. 102, 688-696.

Cheung, N. K., Cheung, I. Y., Canete, A., Yeh, S. J., Kushner, B., Bonilla, M. A., et al. (1994). Antibody response to murine anti-GD2 monoclonal antibodies: correlation with patient survival. Cancer Res. 54, 2228-2233.

Cheung, N. K., Guo, H. F., Heller, G., and Cheung, I. Y. (2000). Induction of $\mathrm{Ab} 3$ and $\mathrm{Ab}^{\prime}$ antibody was associated with long-term survival after anti-G(D2) antibody therapy of stage 4 neuroblastoma. Clin. Cancer Res. 6 , 2653-2660

Chou, M. Y., Fogelstrand, L., Hartvigsen, K., Hansen, L. F., Woelkers, D., Shaw, P. X., et al. (2009). Oxidation-specific epitopes are dominant targets of innate natural antibodies in mice and humans. J. Clin. Invest. 119, 1335-1349.

de Leon, J., Fernandez, A., Mesa, C., Clavel, M., and Fernandez, L. E. (2006). Role of tumour-associated $N$-glycolylated variant of GM3 ganglioside in cancer progression: effect over CD4 expression on $\mathrm{T}$ cells. Cancer Immunol. Immunother. 55, 443-450.

De Maria, R., Lenti, L., Malisan, F., D'Agostino, F., Tomassini, B. Zeuner, A., et al. (1997). Requirement for GD3 ganglioside in CD95- and ceramide-induced apoptosis. Science 277, 1652-1655.

De Maria, R., Rippo, M. R., Schuchman, E. H., and Testi, R. (1998). Acidic sphingomyelinase (ASM) is necessary for fas-induced GD3 ganglioside accumulation and efficient apoptosis of lymphoid cells. J. Exp. Med. 187, 897-902.

Devine, P. L., Clark, B. A., Birrell, G. W., Layton, G. T., Ward, B. G., Alewood, P. F., et al. (1991). The breast tumorassociated epitope defined by monoclonal antibody 3E1.2 is an O-linked mucin carbohydrate containing $\mathrm{N}$ glycolylneuraminic acid. Cancer Res. 51, 5826-5836.

Diatlovitskaia, E. V., Kliuchareva, E. V., Matveeva, V. A., Sinitsyna, E. V., and Akhmed-Zade, A. (1985). Effect of gangliosides on the cytotoxic activity of natural killers from Syrian hamsters. Biokhimiia 50, 1514-1516.

Diaz, A., Alfonso, M., Alonso, R. Saurez, G., Troche, M., Catala, M., et al. (2003). Immune responses in breast cancer patients immunized with an anti-idiotype antibody mimicking NeuGc-containing gangliosides. Clin. Immunol. 107, 80-89.

Eichmann, K., and Rajewsky, K. (1975). Induction of $\mathrm{T}$ and $\mathrm{B}$ cell immunity by anti-idiotypic antibody. Eur. J. Immunol. 5, 661-666.

Feizi, T. (1985). Demonstration by monoclonal antibodies that carbohydrate structures of glycoproteins and glycolipids are onco-developmental antigens. Nature 314, 53-57.

Fishman, P. H. (1974). Normal and abnormal biosynthesis of gangliosides. Chem. Phys. Lipids 13 305-326.

Foon, K. A., Lutzky, J., Baral, R. N., Yannelli, J. R., Hutchins, L., Teitelbaum, A., et al. (2000). Clinical and immune responses in advanced melanoma patients immunized with an anti-idiotype antibody mimicking disialoganglioside GD2. J. Clin. Oncol. 18, 376-384.

Foon, K. A., Sen, G., Hutchins, L., Kashala, O. L., Baral, R., Banerjee, M. et al. (1998). Antibody responses in melanoma patients immunized with an anti-idiotype antibody mimicking disialoganglioside GD2. Clin. Cancer Res. 4, 1117-1124

Fredman, P., Hedberg, K., and Brezicka, T. (2003). Gangliosides as therapeutic targets for cancer. BioDrugs 17, 155-167.

Fujitani, M., Kawai, H., Proia, R. L., Kashiwagi, A., Yasuda, H., and Yamashita, T. (2005). Binding of soluble myelin-associated glycoprotein to specific gangliosides induces the association of p75NTR to lipid rafts and signal transduction. J. Neurochem. 94, 15-21.

Giaccone, G., Debruyne, C., Felip, E., Chapman, P. B., Grant, S. C., Millward, M., et al. (2005). Phase III study of adjuvant vaccination with Bec2/bacille Calmette-Guerin in responding patients with limiteddisease small-cell lung cancer (European Organisation for Research and Treatment of Cancer 08971-08971B; Silva Study). J. Clin. Oncol. 23, 68546864.

Gonwa, T. A., Westrick, M. A., and Macher, B. A. (1984). Inhibition of mitogen- and antigen-induced lymphocyte activation by human leukemia cell gangliosides. Cancer Res. 44, 3467-3470.

Grant, S. C., Kris, M. G., Houghton, A. N., and Chapman, P. B. (1999). Long survival of patients with small cell lung cancer after adjuvant treatmen with the anti-idiotypic antibody BEC2 plus Bacillus CalmetteGuerin. Clin. Cancer Res. 5, 1319-1323.

Hakomori, S. (1970). Cell densitydependent changes of glycolipid concentrations in fibroblasts, and loss of this response in virus-transformed cells. Proc. Natl. Acad. Sci. U.S.A. 67 1741-1747.

Hartvigsen, K., Chou, M. Y., Hansen, L. F., Shaw, P. X., Tsimikas, S., Binder C. J., et al. (2009). The role of innate immunity in atherogenesis. J. Lipid Res. 50(Suppl.), S388-S393.

Hedberg, K. M., Dellheden, B., Wikstrand, C. J., and Fredman, P. (2000). Monoclonal anti-GD3 antibodies selectively inhibit the proliferation of human malignant glioma cells in vitro. Glycoconj. J. 17, 717-726.

Heimburg-Molinaro, J., Lum, M., Vijay, G., Jain, M., Almogren, A., and Rittenhouse-Olson, K. (2011). Cancer vaccines and carbohydrate epitopes. Vaccine 29, 8802-8826.

Hensel, F., Hermann, R., Brandlein, S., Krenn, V., Schmausser, B., Geis, S., et al. (2001). Regulation of the new coexpressed CD55 (decay-accelerating factor) receptor on stomach carcinoma cells involved in antibody SC-1-induced apoptosis. Lab. Invest. 81, 1553-1563.

Hernandez, A. M., Rodriguez, M. Lopez-Requena, A., Beausoleil, I., Perez, R., and Vázquez, A. M. (2005). Generation of anti-Neuglycolyl-ganglioside antibodies by immunization with an anti-idiotype monoclonal antibody: a self versus non-self-matter. Immunobiology 210 , 11-21.

Hernandez, A. M., Toledo, D., Martinez, D., Grinan, T., Brito, V., Macias, A., et al. (2008). Characterization of the antibody response against NeuGcGM3 ganglioside elicited in non-small cell lung cancer patients immunized with an anti-idiotype antibody. J. Immunol. 181, 66256634.

Higgins, T. J., Sabatino, A. P., Remold, H. G., and David, J. R. (1978). Possible role of macrophage glycolipids as receptors for migration inhibitory factor (MIF). J. Immunol. 121, 880-886.

Hildebrand, J., Stryckmans, P. A., and Vanhouche, J. (1972). Gangliosides in leukemic and non-leukemic human leukocytes. Biochim. Biophys. Acta 260, 272-278.

Holmberg, D., Forsgren, S., Forni, L. Ivars, F., and Coutinho, A. (1984a)
Idiotypic determinants of natural IgM antibodies that resemble self Ia antigens. Proc. Natl. Acad. Sci. U.S.A. 81, 3175-3179.

Holmberg, D., Forsgren, S., Ivars, F., and Coutinho, A. (1984b). Reactions among IgM antibodies derived from normal, neonatal mice. Eur. J. Immunol. 14, 435-441.

Holmberg, D., Freitas, A. A., Portnoi, D., Jacquemart, F., Avrameas, S., and Coutinho, A. (1986a). Antibody repertoires of normal BALB/c mice: B lymphocyte populations defined by state of activation. Immunol. Rev. 93, 147-169.

Holmberg, D., Portnoi, D., Jacquemart, F., Forsgren, S., Araujo, P., Andrade, L., et al. (1986b). The repertoire of naturally activated $B$ cells suggests the functionality of the idiotypic network. Ann. Inst. Pasteur Immunol. 137C, 85-87.

Holmberg, D., Wennerstrom, G., Andrade, L., and Coutinho, A. (1986c). The high idiotypic connectivity of "natural" newborn antibodies is not found in adult mitogen-reactive B cell repertoires. Eur. J. Immunol. 16, 82-87.

Holmgren, J., Elwing, H., Fredman, P., Strannegard, O., and Svennerholm, L. (1980a). Gangliosides as receptors for bacterial toxins and Sendai virus. $A d v$. Exp. Med. Biol. 125, 453-470.

Holmgren, J., Svennerholm, L., Elwing, H., Fredman, P., and Strannegard, O. (1980b). Sendai virus receptor: proposed recognition structure based on binding to plastic-adsorbed gangliosides. Proc. Natl. Acad. Sci. U.S.A. 77, 1947-1950.

Holmgren, J., Lonnroth, I., and Svennerholm, L. (1973). Tissue receptor for cholera exotoxin: postulated structure from studies with GM1 ganglioside and related glycolipids. Infect. Immun. 8, 208-214.

Hooijkaas, H., Benner, R., Pleasants, J. R., and Wostmann, B. S. (1984). Isotypes and specificities of immunoglobulins produced by germ-free mice fed chemically defined ultrafiltered "antigen-free" diet. Eur. J. Immunol. 14, 1127-1130.

Irie, A., Koyama, S., Kozutsumi, Y., Kawasaki, T., and Suzuki, A. (1998). The molecular basis for the absence of N-glycolylneuraminic acid in humans. J. Biol. Chem. 273, 15866-15871.

Irie, A., and Suzuki, A. (1998). CMP$\mathrm{N}$-acetylneuraminic acid hydroxylase is exclusively inactive in humans. Biochem. Biophys. Res. Commun. 248, 330-333.

Jakobisiak, M., Lasek, W., and Golab, J. (2003). Natural mechanisms 
protecting against cancer. Immunol. Lett. 90, 103-122.

Jerne, N. K. (1974). Towards a network theory of the immune system. Ann. Immunol. (Paris) 125C, 373-389.

Jerne, N. K. (1985). The generative grammar of the immune system. Science 229, 1057-1059.

Jiang, C., Zhao, M. L., Scearce, R. M., and Diaz, M. (2011). Activation-induced deaminasedeficient MRL/lpr mice secrete high levels of protective antibodies against lupus nephritis. Arthritis Rheum. 63, 1086-1096.

Kailayangiri, S., Altvater, B., Meltzer, J., Pscherer, S., Luecke, A., Dierkes, C., et al. (2012). The ganglioside antigen $G(D 2)$ is surface-expressed in Ewing sarcoma and allows for MHCindependent immune targeting. Br. J. Cancer 106, 1123-1133.

Kato, I., and Naiki, M. (1976). Ganglioside and rabbit erythrocyte membrane receptor for staphylococcal alpha-toxin. Infect. Immun. 13, 289-291.

Kawai, T., Kato, A., Higashi, H., Kato, S., and Naiki, M. (1991). Quantitative determination of $\mathrm{N}$ glycolylneuraminic acid expression in human cancerous tissues and avian lymphoma cell lines as a tumor-associated sialic acid by gas chromatography-mass spectrometry. Cancer Res. 51, 1242-1246.

Kearney, J. F., and Vakil, M. (1986). Idiotype-directed interactions during ontogeny play a major role in the establishment of the adult B cell repertoire. Immunol. Rev. 94, 39-50.

Keranen, A., Lempinen, M., and Puro, K. (1976). Ganglioside pattern and neuraminic acid content of human gastric and colonic carcinoma. Clin. Chim. Acta 70, 103-112.

Kimata, H., and Yoshida, A. (1996). Inhibition of spontaneous immunoglobulin production by ganglioside GM2 in human B cells. Clin. Immunol. Immunopathol. 79, 197-202.

Kirschnek, S., Paris, F., Weller, M., Grassme, H., Ferlinz, K., Riehle, A., et al. (2000). CD95-mediated apoptosis in vivo involves acid sphingomyelinase. J. Biol. Chem. 275, 27316-27323.

Kleinman, H. K., Martin, G. R., and Fishman, P. H. (1979). Ganglioside inhibition of fibronectin-mediated cell adhesion to collagen. Proc. Natl. Acad. Sci. U.S.A. 76, 3367-3371.

Koprowski, H., Herlyn, D., Lubeck, M., Defreitas, E., and Sears, H. F. (1984). Human anti-idiotype antibodies in cancer patients: is the modulation of the immune response beneficial for the patient? Proc. Natl. Acad. Sci. U.S.A. 81, 216-219.

Krug, L. M., Ragupathi, G., Hood, C. Kris, M. G., Miller, V. A., Allen, J. R., etal. (2004). Vaccination of patients with small-cell lung cancer with synthetic fucosyl GM-1 conjugated to keyhole limpet hemocyanin. Clin. Cancer Res. 10, 6094-6100.

Kunkel, H. G., Mannik, M., and Williams, R. C. (1963). Individual antigenic specificity of isolated antibodies. Science 140, 1218-1219.

Ladisch, S., Gillard, B., Wong, C., and Ulsh, L. (1983). Shedding and immunoregulatory activity of YAC-1 lymphoma cell gangliosides. Cancer Res. 43, 3808-3813.

Ladisch, S., Ulsh, L., Gillard, B., and Wong, C. (1984). Modulation of the immune response by gangliosides. Inhibition of adherent monocyte accessory function in vitro. J. Clin. Invest. 74, 2074-2081.

Langman, R., and Cohn, M. (1986) The "complete" idiotypic network is an absurd immune system. Immunol. Today 7, 100-101.

Lardone, R. D., Alaniz, M. E., Irazoqui, F. J., and Nores, G. A. (2006). Unusual presence of anti-GM1 IgGantibodies in a healthy individual, and their possible involvement in the origin of disease-associated antiGM1 antibodies. J. Neuroimmunol. 173, 174-179.

Ledley, F. D., Lee, G., Kohn, L. D., Habig, W. H., and Hardegree, M. C. (1977) Tetanus toxin interactions with thyroid plasma membranes. Implications for structure and function of tetanus toxin receptors and potential pathophysiological significance. $J$. Biol. Chem. 252, 4049-4055.

Lee, G., Aloj, S. M., Brady, R. O., and Kohn, L. D. (1976). The structure and function of glycoprotein hormone receptors: ganglioside interactions with human chorionic gonadotropin. Biochem. Biophys. Res. Commun. 73 370-377.

Lee, G., Aloj, S. M., and Kohn, L. D. (1977). The structure and function of glycoprotein hormone receptors: ganglioside interactions with luteinizing hormone. Biochem. Biophys. Res. Commun. 77, 434-441.

Lee, V. K., Harriott, T. G., Kuchroo, V. K., Halliday, W. J., Hellstrom, I., and Hellstrom, K. E. (1985). Monoclonal antiidiotypic antibodies related to a murine oncofetal bladder tumor antigen induce specific cell-mediated tumor immunity. Proc. Natl. Acad. Sci. U.S.A. 82, 6286-6290.

Lengle, E. E., Krishnaraj, R., and Kemp, R. G. (1979). Inhibition of the lectin-induced mitogenic response of thymocytes by glycolipids. Cancer Res. 39, 817-822.

Lutz, H. U., Binder, C. J., and Kaveri, S. (2009). Naturally occurring autoantibodies in homeostasis and disease. Trends Immunol. 30, 43-51.

Lutz, H. U., and Miescher, S. (2008). Natural antibodies in health and disease: an overview of the first international workshop on natural antibodies in health and disease. Autoimmun. Rev. 7, 405-409.

Malykh, Y. N., Schauer, R., and Shaw, L. (2001). N-glycolylneuraminic acid in human tumours. Biochimie 83, 623-634.

Marquina, G., Waki, H., Fernandez, L. E., Kon, K., Carr, A., Valiente, O., et al. (1996). Gangliosides expressed in human breast cancer. Cancer Res. 56, 5165-5171.

McCaffery, M., Yao, T. J., Williams, L., Livingston, P. O., Houghton, A. N., and Chapman, P. B. (1996). Immunization of melanoma patients with BEC2 anti-idiotypic monoclonal antibody that mimics GD3 ganglioside: enhanced immunogenicity when combined with adjuvant. Clin. Cancer Res. 2, 679-686.

Miller, H. C., and Esselman, W. J. (1975). Modulation of the immune response by antigen-reactive lymphocytes after cultivation with gangliosides. J. Immunol. 115, 839-843.

Miller, R. A., Maloney, D. G., Warnke, R., and Levy, R. (1982). Treatment of B-cell lymphoma with monoclonal anti-idiotype antibody. N. Engl. J. Med. 306, 517-522.

Miura, T., Handa, S., and Yamakawa, T. (1979). Specific inhibition of macrophage migration inhibition factor by fucosylated glycolipid RM. J. Biochem. 86, 773-776.

Mizutamari, R. K., Wiegandt, H., and Nores, G. A. (1994). Characterization of anti-ganglioside antibodies present in normal human plasma. $J$. Neuroimmunol. 50, 215-220.

Mukerjee, S., Nasoff, M., Mcknight, M., and Glassy, M. (1998). Characterization of human IgG1 monoclonal antibody against gangliosides expressed on tumor cells. Hybridoma 17, 133-142.

Mullin, B. R., Fishman, P. H., Lee, G., Aloj, S. M., Ledley, F. D., Winand, R. J., et al. (1976). Thyrotropinganglioside interactions and their relationship to the structure and function of thyrotropin receptors. Proc. Natl. Acad. Sci. U.S.A. 73, 842-846.

Neninger, E., Diaz, R. M., De La Torre, A., Rives, R., Diaz, A., Saurez, G., et al. (2007). Active immunotherapy with $1 \mathrm{E} 10$ anti-idiotype vaccine in patients with small cell lung cancer: report of a phase I trial. Cancer Biol. Ther. 6, 145-150.

Nguyen, D. H., Tangvoranuntakul, P., and Varki, A. (2005). Effects of natural human antibodies against a nonhuman sialic acid that metabolically incorporates into activated and malignant immune cells. J. Immunol. 175, 228-236.

Nudelman, E., Hakomori, S., Kannagi, R., Levery, S., Yeh, M. Y., Hellstrom, K. E., et al. (1982). Characterization of a human melanoma-associated ganglioside antigen defined by a monoclonal antibody, 4.2. J. Biol. Chem. 257, 12752-12756.

Ochsenbein, A. F., Fehr, T., Lutz, C., Suter, M., Brombacher, F., Hengartner, H., et al. (1999). Control of early viral and bacterial distribution and disease by natural antibodies. Science 286, 2156-2159.

Olson, M. V., and Varki, A. (2003). Sequencing the chimpanzee genome: insights into human evolution and disease. Nat. Rev. Genet. 4, 20-28.

Ollert, M. W., David, K., Vollmert, C., Juhl, H., Erttmann, R., Bredehorst, R., et al. (1997). Mechanisms of in vivo anti-neuroblastoma activity of human natural IgM. Eur. J. Cancer 33, 1942-1948.

Oudin, J., and Michel, M. (1963). Une novelle forme d'allotypie des globulines gamma du sérum lapin apparement liée à la fonction et à la spécifité anticorps. $C R$ Acad. Sci. Hebd. Seances Acad. Sci. D 257, 4.

Padler-Karavani, V., Yu, H., Cao, H., Chokhawala, H., Karp, F., Varki, N., et al.. (2008). Diversity in specificity, abundance, and composition of anti-Neu5Gc antibodies in normal humans: potential implications for disease. Glycobiology 18, 818-830.

Partington, C. R., and Daly, J. W. (1979). Effect of gangliosides on adenylate cyclase activity in rat cerebral cortical membranes. Mol. Pharmacol. 15, 484-491.

Pereira, P., Forni, L., Larsson, E. L., Cooper, M., Heusser, C., and Coutinho, A. (1986). Autonomous activation of $\mathrm{B}$ and $\mathrm{T}$ cells in antigenfree mice. Eur. J. Immunol. 16, 685-688.

Pereira, P., Larsson, E. L., Forni, L., Bandeira, A., and Coutinho, A. (1985). Natural effector $\mathrm{T}$ lymphocytes in normal mice. Proc. Natl. Acad. Sci. U.S.A. 82, 7691-7695.

Perez, A., Mier, E. S., Vispo, N. S., Vázquez, A. M., and Perez Rodriguez, R. (2002). A monoclonal antibody against NeuGc-containing gangliosides contains a regulatory idiotope 
involved in the interaction with $\mathrm{B}$ and T cells. Mol. Immunol. 39, 103-112.

Portoukalian, J., Zwingelstein, G., Dore, J. F., and Bourgoin, J. J. (1976). Studies of a ganglioside fraction extracted from human malignant melanoma. Biochimie 58, 1285-1287.

Poste, G., Kirsh, R., and Fidler, I. J. (1979). Cell surface receptors for lymphokines. I. The possible role of glycolipids as receptors for macrophage migration inhibitory factor (MIF) and macrophage activation factor (MAF). Cell. Immunol. 44 71-88.

Ravindranath, M. H., Tsuchida, T., Morton, D. L., and Irie, R. F. (1991). Ganglioside GM3:GD3 ratio as an index for the management of melanoma. Cancer 67, 3029-3035.

Ravindranath, M. H., Yesowitch, P., Sumobay, C., and Morton, D. L. (2007). Glycoimmunomics of human cancer: current concepts and future perspectives. Future Oncol. 3, 201-214.

Ravindranath, R. M., Ravindranath, M. H., and Graves, M. C. (1997). Augmentation of natural antiganglioside IgM antibodies in lower motor neuron disease (LMND) and role of $\mathrm{CD}^{+} \mathrm{B}$ cells. Cell Mol. Life Sci. 53 , 750-758.

Raychaudhuri, S., Saeki, Y., Fuji, H., and Kohler, H. (1986).Tumorspecific idiotype vaccines. I. Generation and characterization of internal image tumor antigen. J. Immunol. 137, 1743-1749.

Retter, M. W., Johnson, J. C., Peckham, D. W., Bannink, J. E., Bangur, C. S. Dresser, K., et al. (2005). Characterization of a proapoptotic antiganglioside GM2 monoclonal antibody and evaluation of its therapeutic effect on melanoma and small cell lung carcinoma xenografts. Cancer Res. 65 , 6425-6434.

Ritter, G., Boosfeld, E., Adluri, R. Calves, M., Oettgen, H. F., Old, L. J., et al. (1991). Antibody response to immunization with ganglioside GD3 and GD3 congeners (lactones, amide and gangliosidol) in patients with malignant melanoma. Int. J. Cancer 48, 379-385.

Roque-Navarro, L., Chakrabandhu, K., De Leon, J., Rodriguez, S., Toledo, C., Carr, A., etal. (2008). Antiganglioside antibody-induced tumor cell death by loss of membrane integrity. Mol. Cancer Ther. 7, 2033 2041.

Sakiyama, H., Gross, S. K., and Robbins, P. W. (1972). Glycolipid synthesis in normal and virus-transformed hamster cell lines. Proc. Natl. Acad. Sci. U.S.A. $69,872-876$
Saleh, M. N., Stapleton, J. D., Khazaeli, M. B., and Lobuglio, A. F. (1993). Generation of a human antiidiotypic antibody that mimics the GD2 antigen. J. Immunol. 151, 33903398.

Schultes, B. C., Baum, R. P., Niesen, A., Noujaim, A. A., and Madiyalakan, R. (1998). Anti-idiotype induction therapy: anti-CA125 antibodies (Ab3) mediated tumor killing in patients treated with Ovarex mAb B43.13 (Ab1). Cancer Immunol. Immunother. 46, 201-212.

Schwartz-Albiez, R., Monteiro, R. C., Rodriguez, M., Binder, C. J., and Shoenfeld, Y. (2009). Natural antibodies, intravenous immunoglobulin and their role in autoimmunity, cancer and inflammation. Clin. Exp. Immunol. 158(Suppl. 1), 43-50.

Sen, G., Chakraborty, M., Foon, K. A., Reisfeld, R. A., and BhattacharyaChatterjee, M. B. (1998). Induction of IgG antibodies by an antiidiotype antibody mimicking disialoganglioside GD2. J. Immunother. 21, 75-83.

Silverman, G. J., Gronwall, C., Vas, J., and Chen, Y. (2009). Natural autoantibodies to apoptotic cell membranes regulate fundamental innate immune functions and suppress inflammation. Discov. Med. 8, 151-156.

Simpson, L. L., and Rapport, M. M. (1971a). The binding of botulinum toxin to membrane lipids: sphingolipids, steroids and fatty acids. $J$. Neurochem. 18, 1751-1759.

Simpson, L. L., and Rapport, M. M. (1971b). Ganglioside inactivation of botulinum toxin. J. Neurochem. 18, 1341-1343.

Sorice, M., Parolini, I., Sansolini, T., Garofalo, T., Dolo, V., Sargiacomo, M., et al. (1997). Evidence for the existence of gangliosideenriched plasma membrane domains in human peripheral lymphocytes. $J$. Lipid Res. 38, 969-980.

Sorice, M., Pavan, A., Misasi, R., Sansolini, T., Garofalo, T., Lenti, L. et al. (1995). Monosialoganglioside GM3 induces CD4 internalization in human peripheral blood $\mathrm{T}$ lymphocytes. Scand. J. Immunol. 41, 148-156.

Stoehr, A. D., Schoen, C. T., Mertes, M. M., Eiglmeier, S., Holecska, V., Lorenz, A. K., et al. (2011). TLR9 in peritoneal $\mathrm{B}-1 \mathrm{~b}$ cells is essential for production of protective selfreactive IgM to control Th17 cells and severe autoimmunity. J. Immunol. 187, 2953-2965.

Storr, S. J., Chakrabarti, J., Barnes A., Murray, A., Chapman, C. J., and Robertson, J. F. (2006). Use of autoantibodies in breast cancer screening and diagnosis. Expert Rev. Anticancer Ther. 6, 12151223.

Svennerholm, L. (1980). Gangliosides and synaptic transmission. Adv. Exp. Med. Biol. 125, 533-544.

Tai, T., Cahan, L. D., Tsuchida, T. Saxton, R. E., Irie, R. F., and Morton, D. L. (1985). Immunogenicity of melanoma-associated gangliosides in cancer patients. Int. J. Cancer 35 , 607-612.

Tangvoranuntakul, P., Gagneux, P., Diaz, S., Bardor, M., Varki, N., Varki, A., et al. (2003). Human uptake and incorporation of an immunogenic nonhuman dietary sialic acid Proc. Natl. Acad. Sci. U.S.A. 100, 12045-12050.

Tokuda, N., Zhang, Q., Yoshida, S., Kusunoki, S., Urano, T., and Furukawa, K. (2006). Genetic mechanisms for the synthesis of fucosyl GM1 in small cell lung cancer cell lines. Glycobiology 16, 916-925.

Urbain, J., Wikler, M., Franssen, J. D. and Collignon, C. (1977). Idiotypic regulation of the immune system by the induction of antibodies agains anti-idiotypic antibodies. Proc. Natl. Acad. Sci. U.S.A. 74, 5126-5130.

Van Heyningen, W. E., Carpenter, C. C. Pierce, N. F., and Greenough, W. B. III. (1971). Deactivation of cholera toxin by ganglioside. J. Infect. Dis. 124, 415-418.

Varela, F. J., and Coutinho, A. (1991). Second generation immune networks. Immunol. Today 12, 159-166.

Vázquez, A. M., Alfonso, M., Lanne, B., Karlsson, K. A., Carr, A., Barroso, O. et al. (1995). Generation of a murine monoclonal antibody specific for $N$ glycolylneuraminic acid-containing gangliosides that also recognizes sulfated glycolipids. Hybridoma 14, 551556.

Vázquez, A. M., Perez, A., Hernandez, A. M., Macias, A., Alfonso, M., Bombino, G., et al. (1998). Syngeneic anti-idiotypic monoclonal antibodies to an antiNeuGc-containing ganglioside monoclonal antibody. Hybridoma 17, 527-534.

Vengris, V. E., Reynolds, F. H. Jr., Hollenberg, M. D., and Pitha, P. M. (1976). Interferon action: role of membrane gangliosides. Virology 72 , 486-493.

Vollmers, H. P., and Brandlein, S (2005). The "early birds": natural IgM antibodies and immune surveillance. Histol. Histopathol. 20, 927-937.

Vollmers, H. P., and Brandlein, S. (2006). Natural IgM antibodies: the orphaned molecules in immune surveillance. Adv. Drug Deliv. Rev. 58, 755-765.

Watanabe, T., Pukel, C. S., Takeyama, H., Lloyd, K. O., Shiku, H., Li, L. T., et al. (1982). Human melanoma antigen $\mathrm{AH}$ is an autoantigenic ganglioside related to GD2. J. Exp. Med. $156,1884-1889$.

Webb, T. J., Li, X., Giuntoli, R. L. II, Lopez, P. H., Heuser, C., Schnaar, R. L., et al. (2012). Molecular identification of GD3 as a suppressor of the innate immune response in ovarian cancer. Cancer Res. 72, 3744-3752.

Werwitzke, S., Trick, D., Kamino, K., Matthias, T., Kniesch, K., Schlegelberger, B., et al. (2005). Inhibition of lupus disease by anti-doublestranded DNA antibodies of the IgM isotype in the $(\mathrm{NZB} \times \mathrm{NZW})$ F1 mouse. Arthritis Rheum. 52, 3629-3638.

Whisler, R. L., and Yates, A. J. (1980). Regulation of lymphocyte responses by human gangliosides. I. Characteristics of inhibitory effects and the induction of impaired activation. J. Immunol. 125, 2106-2111.

Woolley, D. W., and Gommi, B. W. (1965). Serotonin receptors, VII. Activities of various pure gangliosides as the receptors. Proc. Natl. Acad. Sci. U.S.A. 53, 959-963.

Yin, J., Hashimoto, A., Izawa, M., Miyazaki, K., Chen, G. Y., Takematsu, H., etal. (2006). Hypoxic culture induces expression of sialin, a sialic acid transporter, and cancerassociated gangliosides containing non-human sialic acid on human cancer cells. Cancer Res. 66, 29372945.

Yogeeswaran, G., and Hakomori, S. (1975). Cell contact-dependent ganglioside changes in mouse 3T3 gibroblasts and a suppressed sialidase activity on cell contact. Biochemistry 14, 2151-2156.

Zeng, G., Gao, L., Birkle, S., and Yu, R. K. (2000). Suppression of ganglioside GD3 expression in a rat F-11 tumor cell line reduces tumor growth, angiogenesis, and vascular endothelial growth factor production. Cancer Res. 60, 6670-6676.

Zhang, J. Y., Casiano, C. A., Peng, X. X., Koziol, J. A., Chan, E. K., and Tan, E. M. (2003). Enhancement of antibody detection in cancer using panel of recombinant tumor-associated antigens. Cancer Epidemiol. Biomarkers Prev. 12, 136-143.

Zhang, S., Zhang, H. S., Reuter, V. E., Slovin, S. F., Scher, H. I., and Livingston, P. O. (1998). Expression of potential target antigens for immunotherapy on primary 
and metastatic prostate cancers. Clin. Cancer Res. 4, 295-302.

Zhu, A., and Hurst, R. (2002). Anti-Nglycolylneuraminic acid antibodies identified in healthy human serum. Xenotransplantation 9 376-381.

Conflict of Interest Statement: Dr. Ana M. H. Vázquez is an inventor of patents related with $\mathrm{P} 3 \mathrm{mAb}$ and its anti-idiotypes, however, she has signed the assignment of her rights to the assignee Center of Molecular Immunol ogy. The other authors have no conflicts to report.

Received: 03 August 2012; accepted: 29 October 2012; published online: 20 November 2012.
Citation: Vázquez AMH, RodríguezZhurbenko $N$ and López AMV (2012) Anti-ganglioside anti-idiotypic vaccination: more than molecular mimicry. Front. Oncol. 2:170. doi: 10.3389/fonc. 2012.00170

This article was submitted to Frontiers in Tumor Immunity, a specialty of Frontiers in Oncology.
Copyright (c) 2012 Vázquez, RodríguezZhurbenko and López. This is an openaccess article distributed under the terms of the Creative Commons Attribution License, which permits use, distribution and reproduction in other forums, provided the original authors and source are credited and subject to any copyright notices concerning any third-party graphics etc. 